\title{
The Impact of Real Exchange Rate and its Misalignment on Export Performance in Sri Lanka
}

\author{
Sunanda Obeysekera ${ }^{12}$ and Hemantha K.J Ekanayake Ek $^{12}$
}

\begin{abstract}
This paper examines Real Exchange Rate (RER) misalignment and its impact on export performance of Sri Lanka using quarterly data from 2001 to 2016. The results suggest that the RER in Sri Lanka was misaligned in a wide range during this period, with the range narrowing to less than $+/-7$ per cent in recent years. Export functions estimated against several variables including RER and its divergence from equilibrium, separately for three main categories of exports -total exports, industrial exports and textile and garments exports -suggest that that RER undervaluation does not have a statistically significant impact on any of these export categories in the long run. However, there is evidence that the RER is a statistically significant determinant of exports in the short run. In the long run, the production capacity has been identified as the major determinant of industrial exports while the trading partner's income plays a significant role in the case of textile and garment exports. This leads to the conclusion that any policy direction pertaining to addressing the long run growth of exports needs to be associated with enhancement of production capacity though short run impulsion could be provided through RER undervaluation
\end{abstract}

Key Words: Real Exchange Rate, Misalignment, Export Volume, Error Correction Model

JEL Classification: C51; F14; F53

\footnotetext{
${ }^{1}$ The authors wish to thank Prof. Premachandra Athukorala of the Australian National University, Dr. Rahul Annad of the International Monetary Fund (IMF) and Dr. C Amarasekara, Dr. Sumila Wanaguru, Mr. D.L. Nihal, Ms. Erandi Liyanage, Ms. Shanika Dilrukshi of the Central Bank of Sri Lanka for the valuable comments. Corresponding emails: sunanda@,cbsl.lk, hemantha@,cbsl.lk

2 The views presented in this paper are those of the authors and do not necessarily indicate the views of the Central Bank of Sri Lanka
} 


\section{Introduction}

Managing the Real Exchange Rate (RER) in a competitive horizon is one of the biggest conundrums faced by policy makers in developing open economies. According to the "Washington Consensus", RER plays a crucial role in the growth process and views that appropriate RER should be consistent with macroeconomic objectives in the medium term and "sufficiently competitive" 3 such that exports grow at a rate consistent with external balance. However, there have been contravening empirical results where relevant data reflect that a disequilibrium ${ }^{4}$ situation, particularly when RER is more depreciated than the equilibrium, would have a positive influence on international competitiveness and consequently on economic growth. However, there is a limited discussion on the sustainability of RER undervaluation to promote exports in emerging economies, on which this paper attempts to revisit the phenomena in the context of Sri Lanka.

Economists arguing for RER equal or closer to equilibrium, find that any large misalignment of the RER from its equilibrium level hinders economic growth. These studies argue that the RER should be determined by market forces which are consistent with the simultaneous clearing of internal and external accounts. They argue that when it is misaligned, it would generate distortions, producing wrong signals to economic agents causing instability. Aguirre and Calderón (13) has found empirical evidence that both large RER overvaluation and large RER undervaluation hamper economic growth. Haddad and Pancaro (4) has found that in the long run, the effect of RER undervaluation on economic growth becomes negative; and on exports, it becomes insignificant. They further found that an unstable RER leads to more volatile relative prices, creates uncertainty, increases risk, and diminishes investment prospects. Large RER misalignments do not provide the right incentives for investment over time while they depress the quality of investment.

However, the economists in favour of RER disequilibrium argue that undervaluation facilitates growth among developing countries, sighting attainment of enhanced economic growth by East-Asian economies with undervalued currencies. They stress the role of relative prices of tradable and non-tradable goods as an instrument of industrial policy in the process of economic convergence (Hausmann et al. 15; Rodrik, 366). Korinek and Servén (40) showed that RER undervaluation can raise growth through learning-by-doing externalities in the tradables sector that are sub optimally produced in the absence of policy intervention. Aizenman and Lee (1) claim that activist exchange rate policies may generate competitive gains through keeping RER undervalued and the resultant increase in exports will promote

\footnotetext{
${ }^{3}$ However, an excessively competitive RER would not be appropriate since such a rate would enhance inflation and limit resources available for investment.

${ }^{4}$ Disequilibrium in RER refers to a situation in which a country's actual RER deviates from some notion of an implicit "equilibrium" RER. The RER is identified as "undervalued" when it is more depreciated than this equilibrium and "overvalued" when it is more appreciated than this equilibrium ( Razin and Collins, 1997).
} 
economic growth. On the contrary, any appreciation of RER increases the cost of production of goods (including tradable) compared to the rest of the world reducing the competitiveness (Bouoiyour and Rey 309, Rajan et al., 994, Pick and Vollrath, 563). A positive relationship between RER depreciation and exports performance has been revealed by Athukorala (21) for Thailand and by Jongwanich (29) in his paper for developing Asia. However, it would be important to note that Athukorala and Mennon (21) found that the exchange rate policy may be less effective in the determination of exports in countries where component trade is high and growing.

Despite arguments prevail for undervaluation or to keep RER closer to equilibrium, it is important to understand that most of the developing countries that have shown a positive comovement between the RER undervaluation and growth have been developing nations with larger resource base such as China, India and South Korea. These have been the countries that have received a substantial portion of foreign inflow starting from 1990s through FDIs and exports. This led to a massive accumulation of foreign assets in these emerging economies which is reflected by an increased amount of international reserves. As a result, these emerging economies seem to have undertaken competitive measures to keep their currencies undervalued and hence, promote exports (Kubota, 1; Cheung et al., 770). Therefore, whether the same co-movement exists in other developing nations, which have not attracted substantial portion of inward capital movement, needs to be empirically validated. In this backdrop, this study aims at empirically validating the link between RER, its misalignment and export performance in the context of Sri Lanka.

Sri Lanka is a small open economy and its foreign exchange policy gradually evolved from a fixed exchange rate regime in 1948 to an independently floating regime by 2001. However, it has been noted that the Central Bank of Sri Lanka (CBSL) has been following a defensive policy on exchange rate against the dollar since very beginning. This has driven the exports share in GDP to decline while imports have increased disproportionately. The Sri Lankan exports have declined continuously as a share of global exports while as a share of GDP have declined from 33.3 per cent in 2000 to 12.7 per cent in 2016. Many analysts have sighted that the RER misalignment, as the fundamental issue associated with the decline in export share against the increasing trajectory of imports (Kalegama, 44). Meanwhile, certain other analysts' sight high and volatile interest rates, uneven trade policies, increase in wage rates in the domestic labor market and high energy cost as the fundamental reasons behind low performance in the trading sector. The abolition of Multi-fiber Arrangement (MFA) in 2005, which prohibited preferential access to the US apparel market, and loss of concessional access to the EU market under the preferential tariff system GSP+ from October 2010 are other factors that affected severely on the competitiveness of Sri Lanka's exports (Athukorale 26). However, the role of RER and its undervaluation on exports in Sri Lanka is yet to be revealed. In this backdrop, this study aims at investigating the importance of RER and its misalignment in enhancing export performance in Sri Lanka. Since the RER misalignment is an unobservable 
variable, this study first explores the Equilibrium rate of RER (ERER) ${ }^{5}$ using the Behavioral Equilibrium Exchange Rate (BEER) approach using macroeconomic fundamentals and derives the misalignment of RER pertaining to Sri Lanka. Then, it strives to determine the role of RER and RER misalignment on export performance.

The paper analyzed quarterly data from 2001 to 2016 using error correction model. The results suggest that the RER is misaligned in the range of -6.4 per cent to 23.9 per cent during the period 2001 to 2016. However, in recent years (2008 onwards) the misalignment has been less than $+/-7$ per cent. In order to assess the impact of RER misalignment on export performance, the export function has been estimated for three main categories of exports i.e. total exports, industrial exports and textile and garments exports. Contrary to the expectation, it has been found that RER and its undervaluation, a positive deviation from equilibrium values, does not play a significant role in any of the estimated export functions in the long run. Results reveal that Sri Lankan exports are mainly determined by the production capacity of the economy followed by the trading partners' income. As such, the paper suggests that in order to promote exports, it would be necessary to push the Production Possibility Frontier (PPF) outwards through adoption of more sustaining means, such as enhancing the production capacity of the economy rather than devaluating the currency, which would position Sri Lanka along the existing frontier. However, since it had been found that the RER is a significant determinant of exports in the short run, devaluation of currency would provide a short run impetus to the already ailing export sector.

A remainder of this paper is organized as follows. Section 2 explains the calculation of ERER and its misalignment for Sri Lanka while Section 3 explains the impact of RER misalignment on export performance respectively. Section 4 concludes the paper.

\section{Estimating Real Exchange Rate Misalignment}

In this paper, we strive to investigate the factors affecting exports in Sri Lanka focusing more on RER and its misalignment. Since RER misalignment is an unobservable variable, this study attempts to compute RER misalignment for Sri Lanka prior to estimating export functions.

Compiling RER misalignment consists of two steps. First, it is required to estimate the empirical model to derive equilibrium RER and to obtain model based equilibrium RER values. Next, the misalignment is calculated as the proportional deviation of RER from its predicted values.

\footnotetext{
${ }^{5}$ In order to obtain ERER, this paper also uses the HP filter method. Misalignment derived from the HP filter method shows a similar movement, albeit with different magnitudes ( -9.2 per cent to 10.8 per cent).
} 


\subsection{Modelling the Equilibrium Real Exchange Rate}

Deriving the Equilibrium RER is the most important step in the process of determining RER misalignment. Conceptually, a RER is misaligned when it deviates from the underlying RER that would have prevailed in the absence of price rigidities, frictions and other short run factors (Razin and Collins,1). Such underlying RER is referred to as "Equilibrium RER" (ERER). This, in technical terms, is referred to as theoretical RER, which would have prevailed if the economy is simultaneously in internal and external balance. Internal balance refers to the economy operating at full employment and full capacity output while the external balance refers to a sustainable current account position, given a country's desired capital position, as a net lender or borrower.

There are different views on the ERER expressed in literature. The Fundamental Equilibrium Exchange Rate (FEER) approach defines the ERER as the effective exchange rate that brings the current account at full employment level and the capital account in to an arbitrary equilibrium. Slightly contrastingly, the Behavioral Equilibrium Exchange Rate (BEER) approach expresses ERER as a function of other macroeconomic fundamentals. This study uses the concept of "behavioral equilibrium exchange rate" (BEER), which explains the behavior of real exchange rate in terms of economic fundamentals, using reduced form econometric equations to derive ERER for Sri Lanka.

Macroeconomic fundamentals that determine RER consist of vast sets, yet different studies concentrate on different small subsets. In application of the model based approach, Cottani et al. (1) used Edwards (1) model incorporating terms of trade, an indicator for trade policy openness, the net capital inflows as a ratio of GDP, the domestic credit creation in excess to devaluation, the foreign inflation and the real growth rate. Doroodian et al. (1808) employed a similar model to estimate RER misalignment in Turkey using the terms of trade, the ratio of investment to GDP, an indicator for trade openness, a proxy for technological progress, a proxy for capital control and the government consumption as a ratio of GDP. Yajie et al. (5) employed BEER on China using the Johansen co-integration technique with both long term and short term variables. The IMF consultative group on exchange rate assessment in 2006 applied a model based approach on a group of advanced and emerging countries using relative productivity, a proxy for openness, current account inflows, oil price, the terms of trade, and the government expenditure as variables. Following from the literature, this study uses fundamentals as given in the equation below to estimate the equilibrium RER.

$$
E R E R=f\left(P R O D, T O T, O P E N, N F A, G E X P, I N T D I F F, N e t \_ \text {sales, D1,D2, }\right)
$$

ERER- Equilibrium real exchange rate

PROD- Productivity improvement representing the Balassa Samuelson effect 
TOT- the terms of trade index

OPEN- a proxy for trade openness

NFA - the Net Foreign Assets

GEXP - Government Expenditure

INTDIFF.- Interest rate Differential

Net_sales - Forex sales (net) by the Central Bank

D1- dummy variable to represent post tsunami effect

D2 - dummy variable to represent the period during the civil conflict

Economic theory suggests that an improvement in productivity (PROD) will stimulate the demand for non-tradable goods, resulting in higher domestic prices and consequently real appreciation. Intrinsically, the impact is known as Balassa-Samuelson effect because the productivity improvement in the tradable sector will cause the increase in the wages of those employed in that sector; including higher wages in the non-tradable sector. If this is not accompanied with higher productivity in the non-tradable sector, then an increase in the overall price level will result and consequently real appreciation.

Theoretically, the Terms of Trade's (TOT) influence on the RER cannot be signed a priori, as this depends on whether income or substitution effects dominate. The former leads to real currency appreciation while the latter to real currency depreciation (Edwards 9). Trade openness (OPEN) is expected to have a negative sign, implying that higher the degree of openness results in higher degree of real depreciation as spending will be diverted to the tradable goods sector. Similarly, higher government expenditure (GEXP) is likely to appreciate RER as it falls more on non-tradable goods than tradable goods. However, it primarily depends on whether the increase in the government consumption is directed to the tradable (equivalent to real depreciation) or to non-tradable goods (equivalent to real appreciation). It is also assumed that countries with relatively high Net Foreign Assets (NFA) as well as higher real interest rate differential (INTDIFF) may afford more appreciated RERs. In addition to these fundamentals, the study also uses forex sales by the CBSL and two dummy variables to capture the tsunami period as well as the period under the civil war. The dependent variable, ERER is proxied by 24 currency basket based real effective exchange rate index compiled by the CBSL.

In addition to the model based approach (Equation 1), this study also uses a filter based approach (uni-variate analysis) to compile RER misalignment for Sri Lanka. In the literature filter based methods have been mostly used to estimate the potential output. This merely represents the trend component of the underline series. The extracted trend component of the actual RER is considered as the equilibrium RER. 
Estimated parameters are then use to calculate ERER. In constructing ERER, original variables are filtered excluding the transitory components using the Hodrick-Prescott (HP) filter method. The model based ERER is then used to calculate RER misalignment for Sri Lanka.

\subsubsection{Data and Methodology}

The CBSL started to publish Real Effective Exchange Rate (REER) index based on 24 currency basket since 2001. The REER is computed using exchange rates and prices of Sri Lanka's 24 trading partner countries. The share of each country's bilateral trade with Sri Lanka has been taken into account in arriving at weights. REER is compiled using the equation below:

$$
\mathrm{REER}=\sum_{i=1}^{n}\left[\left(e / e_{i}\right)\left(P / P_{i}\right)\right]^{w_{i}}
$$

where e : Exchange rate of the Sri Lankan Rupee against the US dollar ( US dollars per Rupee)

$e_{i}$ : Exchange rates of currency $i$ against the US dollar (US dollars per currency i)

P : Consumer Price Index (CPI) ${ }^{6}$ of Sri Lanka compared to the base period index

$\mathrm{P}_{\mathrm{i}}$ : CPI of country i

$\mathrm{w}$ : Weights attached to the currency $\mathrm{i}$ in the index

Since the exchange rate is defined as above in computing REER index, appreciation (depreciation) of the Rupee relative to other currencies, ceteris paribus, is reflected by a rise (fall) in the REER index value (Central Bank of Sri Lanka, 2003). Consequently, rising REER ${ }^{7}$ is favourable for imports yet negatively affects exports and vice versa. The index is revised regularly considering the trade patterns between Sri Lanka and partner countries. The most recent series of the index is based on 2010. Partner countries and associated trade weights are listed in Appendix 1.

Other fundamentals, such as terms of trade, net foreign assets, government expenditure and net forex sales are taken from the IMF-IFS data base and the CBSL. Following from the literature, the productivity improvement to represent the Balassa Samuelson effect is proxied by the ratio of Sri Lanka's per capita GDP to the OECD average per capita GDP. Similarly,

\footnotetext{
${ }^{6}$ Due to the non- availability of the producer price index (PPI) data for all countries in the currency basket, the CBSL was compelled to uses CPI (2006/07=100) in place of PPI in compilation of the REER.

${ }^{7}$ Due the formula used in compiling REER in Sri Lanka, when all else is held constant, a depreciation of the rupee against the dollar results in a decline in REER index and vice versa. Therefore, care must be taken in interpreting the appreciation and the depreciation of RER using REER index.
} 
openness is proxied by the ratio of total trade i.e. export plus imports to GDP. Two dummy variables to represent tsunami related capital flows (from q1 2005 to q4 2005) and the civil war period (from q1 2001 to q2 2009) have also been used. Appendix 2 provides the descriptive statistics of data used in the analysis.

\subsubsection{Results and discussion}

The estimation process begins with the determination of the order of integration of the variables under concern. Both the Augmented Dicky-Fuller (ADF) test (table 1) as well as the Philips-Perron (PP) test have been used for this purpose and except for net forex sales all other variables are found to be integrated of order 1(I $(\mathrm{I}))$.

\section{Table 1: Unit Root Test (ADF) Results}

\begin{tabular}{llll}
\hline \hline Variable & Level & 1st Difference & Order of Integration \\
\hline REER(24) & -1.892 & $-4.089 * * *$ & $\mathrm{I}(1)$ \\
Productivity Improvement (PROD) & 2.148 & $-2.036^{* *}$ & $\mathrm{I}(1)$ \\
Net Foreign Assets (NFA) & -2.187 & $-4.880^{* * *}$ & $\mathrm{I}(1)$ \\
Terms of Trade (TOT) & -0.611 & $-9.199 * * *$ & $\mathrm{I}(1)$ \\
Trade as a per cent of GDP (OPEN) & -1.452 & $-4.705^{* * *}$ & $\mathrm{I}(1)$ \\
Government Consumption to GDP (GEXP) & -1.963 & $-9.416^{* * *}$ & $\mathrm{I}(1)$ \\
Interest rate differential (INT_DIFF) & -1.405 & $-6.627^{* * *}$ & $\mathrm{I}(1)$ \\
Net forex sales (Net_Forex) & $-4.097 * * *$ & & $\mathrm{I}(0)$ \\
\hline
\end{tabular}

Notes: The data are in levels. A time trend is included, when necessary, in these tests. The optimum lag length is suggested by SIC. The critical values for the ADF test are from Davidson and MacKinnon (1993, page 708, Table 20.1). ${ }^{* *}, * *, *$ suggest that the null hypothesis is rejected at the 1,5 and 10 percent level respectively.

The Johansen co-intergration test confirmed that these variables are co-integrated in the long run (Table 2). 
Table 2: Johansen Cointegration Test

\begin{tabular}{llllllll}
\hline \hline $\begin{array}{l}\text { Null } \\
\begin{array}{l}\text { Hypo- } \\
\text { hesis }\end{array}\end{array}$ & $\begin{array}{l}\text { Alternative } \\
\text { Hypoth- } \\
\text { esis }\end{array}$ & Trace Stat & $\begin{array}{l}\text { Critical } \\
\text { Value }(0.01)\end{array}$ & $\begin{array}{l}\text { Null } \\
\text { Hypothesi } \\
\mathrm{s}\end{array}$ & $\begin{array}{l}\text { Alternative } \\
\text { Hypothesis }\end{array}$ & $\begin{array}{l}\text { Max- } \\
\text { Eigen } \\
\text { Statistics }\end{array}$ & $\begin{array}{l}\text { Critical } \\
\text { Value (0.01) }\end{array}$ \\
\hline $\mathrm{r}=0$ & $\mathrm{r}>0$ & $174.4275^{*}$ & 121.7433 & $\mathrm{r}=0$ & $\mathrm{r}=1$ & $55.72833^{*}$ & 48.65818 \\
$\mathrm{r} \leq 1$ & $\mathrm{r}>1$ & $118.6992^{*}$ & 92.71365 & $\mathrm{r}=1$ & $\mathrm{r}=2$ & $43.87688^{*}$ & 42.23332 \\
$\mathrm{r} \leq 2$ & $\mathrm{r}>2$ & $74.82231^{*}$ & 67.63668 & & & & \\
\hline
\end{tabular}

* denotes rejection of the hypothesis at the 0.01 level

Accordingly, the Vector Error Correction Model (VECM) is chosen to estimate the long run parameters of RER determinants, allowing for possible bidirectional causality among variables. Net forex sales $\mathrm{I}(0)$ and dummy variables have been used as exogenous variables to the system. The appropriate lag length is selected as one, considering the majority of the lag length selection criteria. ${ }^{8}$

Following the general to specific modeling procedure, the most insignificant variable is removed from the estimation under three stages. In the first stage the model includes all relevant variables explained above (Scenario1). However, it is observed that the dummy variable included representing the tsunami effect is found to be highly insignificant. Therefore, the second stage, the model (Scenario 2) consists of the entire variable set in Stage 1 except for the dummy variable that represents the tsunami impact on REER. In a similar vein, removing the next most insignificant variable from the estimation, i.e. the net forex sales of the CBSL, the final model (Specification 3) has been estimated in the Stage three. ${ }^{9}$ Estimated parameters of the final model are reported in Table 3.

\footnotetext{
${ }^{8}$ Both Schwarz information criterion (SC) and Hannan-Quinn information criterion (HQ) selected one lag.

9 Test results for all three models are available in the Appendix 3.
} 
Table 3: Relationship between REER and its Fundamentals

\begin{tabular}{llllllllll}
\hline \hline Variable & REER24 & C & PROD & NFA & TOT & OPEN & GEXP & INT_DIFF & ECT \\
\hline Coeff. & 1.0 & $-3.34^{* * *}$ & $36.86^{* * *}$ & $.0003^{* * *}$ & $0.28^{* * *}$ & -0.20 & $1.62^{* * *}$ & $1.17^{* * *}$ & $-0.31^{* * *}$ \\
t stat. & & {$[-4.22]$} & {$[-8.19]$} & {$[-4.61]$} & {$[-3.39]$} & {$[1.60]$} & {$[-3.16]$} & {$[-4.26]$} & {$[-4.87]$} \\
\hline
\end{tabular}

***,*** suggest the significance level of 1,5 and 10 percent respectively.

The estimation results are encouraging as estimated signs for all variables coincide with the theoretical and previous empirical findings. Estimated ECT shows that when the system is in disequilibrium it would take about three and a half quarters to come back to the equilibrium. The effect of productivity improvement on RER is found positive and significant, indicating that in Sri Lanka, productivity improvement is concentrated in the tradable goods sector and leads to an appreciation of RER. It is also evident that an improvement in terms of trade (TOT) will appreciate RER. An improving TOT provides a direct income effect, operating through demand for non-tradable goods as an increase in income raises the demand for all goods. Since the import prices are given, tradable good prices do not change but the price of non-tradable goods goes up, appreciating RER. On the other hand, an improving TOT provides more foreign income and suppliers in the non-tradable good sector utilize this income and increase production, leading prices of non-tradable goods to go down. This could lead to a depreciation of RER. The net impact depends on the magnitude of both income and substitution effects. This result shows that for Sri Lanka, the income effect dominates the substitution effect.

The increase in net foreign assets appreciates RER as given in the results. Edwards (2) shows that an increase in foreign inflow may lead to an increase in demand for non-tradable goods, which would in turn raise their prices and appreciate RER. The RER is negatively affected by the trade openness (OPEN). This is also consistent with the theory, as trade openness creates downward pressure on the price of tradable goods versus non-tradable goods (Ghura and Grennes, 2).

\subsection{Compiling the Real Exchange Rate Misalignment for Sri Lanka}

Once the ERER is derived using the estimated parameters in Table 3, the RER misalignment is computed as follows:

Misal $=\underline{\text { RER }- \text { ERER }}$

ERER

RER- actual RER

ERER - the model based Equilibrium RER 
Consequently, positive values of Misalignment (Misal) implies RER overvaluation and vice versa. Undervaluation refers to that domestic prices are low by international standards and domestic producers are competitive. Similarly, overvaluation refers that domestic prices are too high and domestic producers are not competitive.

\section{Figure 1: RER misalignment}

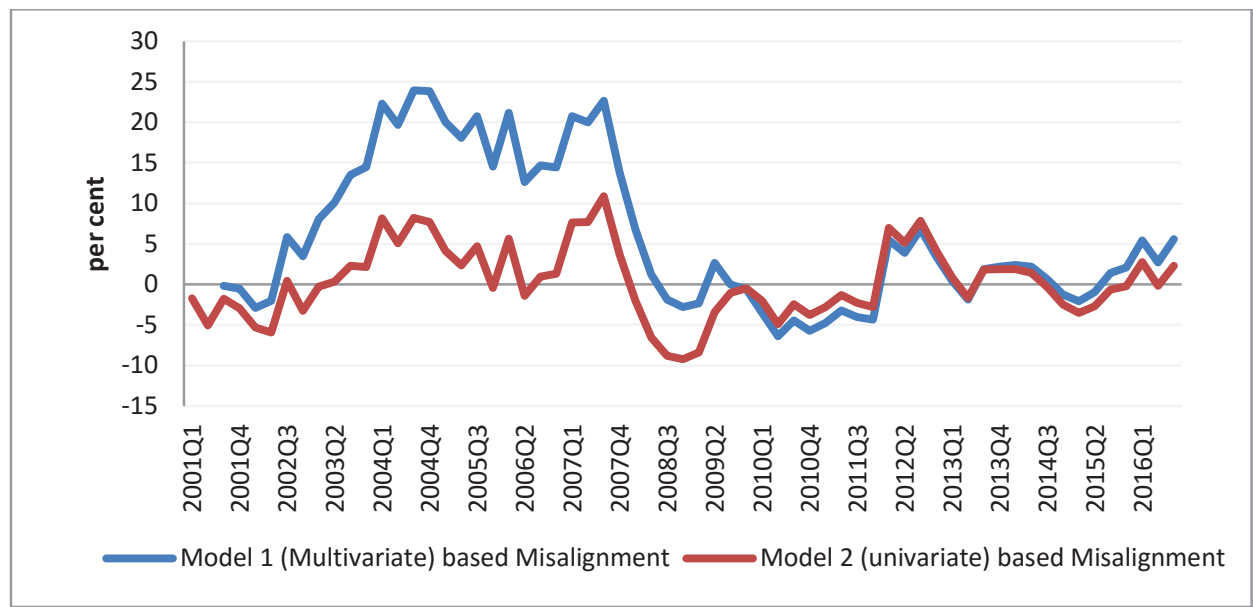

Figure 1 shows that the co-movement of RER misalignment is derived from the filter based method and equation based method. The overvalued RER relative to ERER is reflected by positive deviations and vice versa. Both methodologies indicate similar findings yet with different magnitudes. Based on the multivariate model, the RER misalignment ranged from 6.4 per cent to 23.9 per cent during the period under review. The RER has been highly overvalued during the period from 2002 to 2008. However, from 2008 onwards the RER misalignment has been $+/-7$ per cent, implying the convergence of RER towards ERER in recent years.

\section{Examine the relationship between RER misalignment and export performance}

In general, the export performance is determined jointly by external as well as domestic factors. Following from the literature, we consider all those factors that can potentially play an important role in the determination of exports in a small open economy alongside RER and its misalignment. The trading partner's income is considered as the main demand side determinants of exports, while production capacity represents the key supply side determinant of exports. The relative price i.e. RER, and other international trade related policy concerns affect exports from both demand and supply sides. 


$$
X=f\left(R E R, W D, P C, D_{-} R E R m i s, D_{-} m f a\right)
$$

The dependent variable, $X$, is the export volume index for all selected categories of exports (total exports, industrial exports and textile and garments exports). The trading partner's income is derived by taking the trade weighted average GDP of Sri Lanka's major export trading partners. The production capacity is proxied by the potential industrial GDP while the RER is the quarterly average Real Effective Exchange Rate (REER 24) index. RERmis is the estimated RER misalignment in the previous section. In order to find out the impact of RER overvaluation and undervaluation on export performance, a dummy variable (D_RERmis) is created; one taking positive values of RER misalignment and zero otherwise (Schröder, 2013). In order to capture the positive impact of the Multi Fiber Agreement on exports, a dummy variable is included in the analysis taking 1 for the period up to 2005.

Theoretically, it is expected to have positive link between trading partners' income and export volume as well as between production capacity and export volume. Since the RER is used as an indicator of the country's external competitiveness, an appreciation of REER indicates loss of competitiveness, reducing export volume. Therefore, a negative relationship is expected between the real effective exchange rate and export volume. The dummy variable D_RERmis (overvalued period) is expected to have a negative coefficient, as the overvalued RER would reduce the export volume. D_mfa which indicates the availability of the MFA would enhance the textiles and garments exports, resulting in an increase of export volume.

\subsection{Data and Methodology}

The error correction version of the Auto Regressive Distributed Lag Model (ARDL) approach is chosen for analysis as it provided consistent estimators even when variables of the model are of different order of integration. Further the ARDL model allows for the inclusion of the dynamics of the variables in the analysis, thereby, mitigating the impact of the endogeneity of the explanatory variables to some extent. Besides, it is revealed that in the case of a finite sample, this methodology provides precise estimators and valid $t$ statistics (Pesaran et al., 19; Hendry 64). This paper estimates the long run determinants of export performance by nesting the equation (2) into the ARDL model.

$$
X_{t}=\sum_{k=1}^{p} \delta_{k} X_{t-k}+\sum_{l=0}^{q} \gamma_{j} Z_{j, t-l}+\varepsilon_{t}
$$

In this model the dependent variable, export volume, $(\mathrm{Xt})$ and explanatory variables such as REER 24, Trading Partner's income, production capacity and a dummy variable for RER mis alignment $(\mathrm{Zt})$ are included in the regression with lag of order $\mathrm{p}$ and $\mathrm{q}$. Appendix 4 provides the descriptive statistics of data used in the analysis. 
The error correction version of the ARDL model can be then written as follows;

$$
\Delta X_{t}=\gamma_{1} \Delta Z_{t}-\left(1-\delta_{1}\right)\left[X_{t-1}+\eta_{j} Z_{j, t-1}\right]+\varepsilon_{t}
$$

Where, $\left(1-\delta_{1}\right)$ provides the speed of adjustment towards the long run equilibrium while $\eta_{j} /\left(1-\delta_{1}\right)$, defines the long run relationship between the variables in the estimation.

\subsection{Results and Discussion}

Prior to estimating the above equations it is necessary to check the time series properties by testing the stationarity of the fundamental variables. This study employs the ADF test to determine the order of integration. As illustrated in Table 4, this study finds that the variables under concern are either $\mathrm{I}(0)$ or $\mathrm{I}(1)$.

Table 4: Unit Root Test (ADF) Results

\begin{tabular}{llll}
\hline \hline Variable & Level & 1st Difference & $\begin{array}{c}\text { Order of } \\
\text { Integration }\end{array}$ \\
\hline Total Export Volume & 0.032 & $16.46^{* * *}$ & $\mathrm{I}(1)$ \\
Agriculture Export Volume & 0.205 & $-4.511^{* * *}$ & $\mathrm{I}(1)$ \\
Industrial Export Volume & -0.223 & $-7.884^{* * *}$ & $\mathrm{I}(1)$ \\
REER(24) & -1.892 & $-4.089^{* * *}$ & $\mathrm{I}(1)$ \\
Trading Partners' Income & 0.408 & $-5.233^{* * *}$ & $\mathrm{I}(1)$ \\
Production Capacity & $-5.105^{* * *}$ & & $\mathrm{I}(0)$ \\
RER Misalignment & -1.691 & $-4.024^{* * *}$ & $\mathrm{I}(1)$ \\
\hline
\end{tabular}

Notes: The data are in levels. A time trend is included, when necessary, in these tests. The optimum lag length is suggested by SIC. The critical values for the ADF test are from Davidson and MacKinnon (1993, page 708, Table 20.1). ******* suggest that the null hypothesis is rejected at the 1,5 and 10 percent level respectively.

As mentioned previously, the error correction version of the ARDL approach is employed to estimate the export demand function for Sri Lanka. As the first step of the analysis, it is necessary to test the existence of a long run relationship between the variables under investigation by using the Wald test. Then the Wald test statistic is compared with the bound test critical values tabulated by Pesaran et al. (2001). If the Wald test statistics are greater than 
the upper bound of the critical value, the null hypothesis can be rejected to conclude that a long run relation exists between the variables of concern. If it is smaller than the lower bound critical value, the null hypothesis cannot be rejected. Finally, if it falls within the lower and upper bound, the results become inconclusive. The Wald F test statistics for both models exceed the upper bound critical value (Table 5) and, therefore, the null hypothesis can be rejected, confirming a long-run relationship among the variables of interest.

Table 5: Bound test results

\begin{tabular}{ll}
\hline Model & Wald test F statistic \\
\hline Total Exports function & $25.246^{* * *}$ \\
Industrial Exports function & $13.054^{* * *}$ \\
Textile and garments exports function & $11.974^{* * *}$ \\
\hline
\end{tabular}

Notes: Critical Value for Bound Test (Pesaran et, al 2001, p 300)

intercept and no trend $(\mathrm{k}=4):[3.74,5.06]$ at $1 \%$ and $[2.45,3.52]$ at $10 \%$

$* * *, * *, *$ indicate significance at $1 \%, 5 \%$, and $10 \%$ respectively

The export function has been estimated separately for total exports, industrial exports and exports of textile and garments. The results are reported in Table 6. To increase the reliability of the estimated results, diagnostic tests were carried out for each model and it is found that the models are free from autocorrelation and residuals are normal in distribution. Further, standard errors were obtained in consistence with heteroskedasticity. The results of the Ramsey test show that there are no signs of a mis-specified functional form. The cumulative sum of recursive residuals (CUSUM) and the cumulative sum of squares of recursive residuals (CUSUMSQ) suggest that the estimates are stable (Appendix 5). Therefore, the long run relationship between exports and its determinants, as given in Table 6, is assured.

Contrary to the expectation, it is found that RER overvaluation does not play a significant role in any of the estimated export functions. Similarly, it is revealed that RER itself also does not affect exports significantly in the long run. Nevertheless, in the short run, RER was identified as a significant determinant of exports analyzed under three categories. Obviously, the exports during the previous period appear as the main determinant of total exports in the long run while in the short run, an increase in RER have reduced export volumes significantly. If we move to sub sectors of analysis, in the long run, industrial exports are explained by exports in the previous period and the production capacity whereas in the short run it is primarily dependent on the changes in RER. As expected, an appreciation of RER reduces the volume of industrial exports significantly in the short run. 
In the case of textile and garments, the export volume is primarily dependent on exports in the previous period and trading partners' income. This finding is consistent with recent studies in the literature that find the significant positive link between trading partners' income and textile and garments exports. Athukorale (26) employs the Phillips-Hanses fully modified OLS method for the annual data from 1970 to 2015 and finds that world demand, which is proxied by real manufacturing exports from developing countries, is a significant determinant of the textile and garments exports. Similarly, Ekanayake (2013) estimates the export demand function for textiles and garments using world GDP as a proxy to trading partners' income and finds that the world income has a positive and significant impact on the demand for Sri Lankan textiles and garments. As in the case of other exports, in the short run, textile and garments exports are explained mainly by the changes in RER.

Overall, the results indicate that misaligned RER does not play a significant role in improving exports in Sri Lanka in the long run though it affects exports significantly in the short run. In the long run, the production capacity and trading partner's income play a significant role in improving export performance. The results in relation to textile and garments reflect very important and noteworthy characters of the sector.

The significant determinant in the long run in relation to this sector is the trading partner's income while there is no significant relationship between exports and production capacity. This could be mainly attributable to the quota system under which Sri Lanka operates for a longer period where the income of the trading partners matters for their import volumes. At the same time the contribution from capacity enhancement may matter less significantly owing to the very high standard of capacity the Sri Lankan garments sector maintained for a long period of time. However, when other export functions are considered, trading partners' income does not act as a significant determinant whereas production capacity in the economy plays a vital role.

Findings of this study also support the argument put forward by Haddad and Pancaro (4) which explain that a real undervaluation boost exports only in the medium term. Therefore, even though RER adjustment would enable to provide an impetus to the exports in the short run, an emphasis needs to be placed on enhancing production capacity of the economy to push the production possibility frontier outwards in order to enhance export performance in the long run. 
Table 6: Determinants for Exports for Sri Lanka

\begin{tabular}{|c|c|c|c|}
\hline \multirow[t]{2}{*}{ Independent Variables } & \multicolumn{3}{|c|}{ Dependent Variable } \\
\hline & $\begin{array}{l}\text { Log Difference of } \\
\text { Total Export (Volume } \\
\text { Index) }\end{array}$ & $\begin{array}{l}\text { Log Difference of } \\
\text { Industrial export } \\
\text { (Volume Index) }\end{array}$ & $\begin{array}{l}\text { Log Difference of } \\
\text { Textiles and } \\
\text { Garments export } \\
\text { (Volume Index) }\end{array}$ \\
\hline Constant & $\begin{array}{l}-5.93^{* *} \\
(-5.46)\end{array}$ & $\begin{array}{l}-7.43^{* * *} \\
(-5.52)\end{array}$ & $\begin{array}{c}-1.42 \\
(-0.97)\end{array}$ \\
\hline log Dependent Variable $(-1)$ & $\begin{array}{l}-0.93^{* * *} \\
(-7.28)\end{array}$ & $\begin{array}{l}-0.84^{* * *} \\
(-6.04)\end{array}$ & $\begin{array}{l}-0.92^{* * *} \\
(-5.19)\end{array}$ \\
\hline Log Production Capacity (-1) & $\begin{array}{l}0.58^{* *} \\
(2.2)\end{array}$ & $\begin{array}{l}0.74^{* *} \\
(2.58)\end{array}$ & $\begin{array}{l}-0.004 \\
(-0.009)\end{array}$ \\
\hline $\begin{array}{l}\text { Log trading Partners Real GDP } \\
(-1)\end{array}$ & $\begin{array}{c}0.69 \\
(1.07)\end{array}$ & $\begin{array}{c}0.61 \\
(0.86)\end{array}$ & $\begin{array}{l}1.59^{*} \\
(1.74)\end{array}$ \\
\hline $\log \operatorname{RER}(-1)$ & $\begin{array}{l}-0.13 \\
(-0.73)\end{array}$ & $\begin{array}{l}-0.22 \\
(-1.14)\end{array}$ & $\begin{array}{l}-0.33 \\
(1.51)\end{array}$ \\
\hline $\begin{array}{l}\text { Log Difference of Production } \\
\text { Capacity }\end{array}$ & $\begin{array}{c}4.66 \\
(0.67)\end{array}$ & $\begin{array}{l}-1.76 \\
(0.20)\end{array}$ & $\begin{array}{c}-4.0 \\
(-0.39)\end{array}$ \\
\hline $\begin{array}{l}\text { Log Difference of trading } \\
\text { Partners GDP }\end{array}$ & $\begin{array}{c}0.18 \\
(0.18)\end{array}$ & $\begin{array}{l}-0.39 \\
(-0.36)\end{array}$ & $\begin{array}{c}2.38 \\
(1.68)\end{array}$ \\
\hline Log Difference of RER & $\begin{array}{l}-0.57^{* *} \\
(-2.66)\end{array}$ & $\begin{array}{l}-0.74^{* * *} \\
(-2.99)\end{array}$ & $\begin{array}{l}0.70^{* *} \\
(2.57)\end{array}$ \\
\hline D_RERmis (1 when & $\begin{array}{l}-0.01 \\
(-0.71)\end{array}$ & $\begin{array}{c}0.01 \\
(0.54)\end{array}$ & $\begin{array}{c}0.01 \\
(0.57)\end{array}$ \\
\hline chering & $\begin{array}{l}-0.001 \\
-0.03\end{array}$ & $\begin{array}{c}0.01 \\
(0.27)\end{array}$ & $\begin{array}{c}-0.04 \\
(-0.84)\end{array}$ \\
\hline No of Observations & 59 & 59 & 59 \\
\hline R-squared & 0.56 & 0.52 & 0.53 \\
\hline Diagnostic Tests & & & \\
\hline Serial Correlation(LM) Test & $0.07[0.929]$ & $1.49[0.475]$ & $3.77[0.152]$ \\
\hline Ramsey Test (1 & & & \\
\hline Restrictions) & $0.31[0.574]$ & $2.41[0.101]$ & $0.25[0.775]$ \\
\hline
\end{tabular}

Notes: ***,**,* indicate significance at $1 \%, 5 \%$ and $10 \%$ respectively,

Standard errors have been corrected for presence of heteroscedasticity.

$\mathrm{t}$ statistics are in ( )parenthesis.

Critical values for diagnostic tests are taken from $\mathrm{F}$ distribution table and $\mathrm{p}$ values are in [] 


\section{Conclusion}

This study investigates the impact of RER and its misalignment on export performance in Sri Lanka using quarterly data from 2001 to 2016. First, it quantified the RER misalignment and then examined the effect of misalignment on export performance. Considering time series properties of data chosen for the study, error correction models have been used in the analysis. The estimated results suggest that the RER in Sri Lanka during this period is misaligned in the range of -6.4 per cent to 23.9 per cent during the period 2001 to 2016. Misalignment derived from the HP filter method shows a similar movement, albeit with different magnitudes $(-9.2$ per cent to 10.8 per cent). However, in recent years, from 2008 onwards, the misalignment has been less than $+/-7$ per cent.

In order to assess the impact of RER misalignment on export performance, the export function has been estimated for three main categories i.e. total exports, industrial exports and exports of textile and garments, including a dummy variable to represent the period where RER is undervalued. Contrary to the expectation, it is found that RER undervaluation does not play a significant role in any of the estimated export functions in the long run. However, in the analysis, there are evidences to support that the RER is a significant determinant of exports in the short run. As such Sri Lanka could gain from adjusting RER in favour of exports in the shorter horizon. In the long run, however, the production capacity and trading partner's income play a significant role in improving export performance. It is important to note here that the trading partner's income becomes a significant determinant only in the textile and garments exports while in other sectors it is mainly determined by the production capacity of the economy. Therefore, in order to improve the export performance in the long run, emphasis needs to be placed on enhancing the production capacity of the economy, thereby pushing the production possibility frontier outwards rather than moving along the frontier.

Overall, results suggest that a stable and undervalued RER is fundamentally important in determining the growth in exports sector in the short run, though the impact of maintaining the policy in the longer duration is insignificant. This may even cause adverse consequences according to Haddad and Pancaro (4), as real undervaluation led by nominal depreciation that is not supported by anti-inflationary policies such as wage moderation can cause high and destabilizing liquidity growth and inflation, which could cause financial instability. Moreover, the undervalued currency rate can destabilize the monetary policy, making it incapable of reaching domestic objectives. Such constraints may cause an artificial process of over-lending and over-investment, resulting in overheating of the economy. This artificial undervaluation may provide an incentive to the producers, but this may come at the expense of the consumers who may lose their purchasing power. Finally, it may be difficult to move from the status quo due to the lobbying of the tradable sector.

Finally, any future study pertaining to the RER misalignment and exports sector can be further strengthened through the following adoptions. First, this study focuses on assessing the impact 
of RER misalignment on export performance rather than estimating the comprehensive export function for Sri Lanka. Therefore, in order to provide policy recommendations on improving the export performance of the country, a comprehensive study on exports would be vital. Secondly, this study involves anlaysing the export volumes in relation to the industrial and textile and garments exports against the same variables including RER and RER misalignment. However, it is generally accepted that variables that would impact different categories of exports would differ, warranting separate functions being developed for each sector. Thirdly, in estimating the export function for textile and garments, removing the portion of imported parts and components would be ideal as they are also been affected by the RER movement though to the contrary direction. Finally, it would be ideal if volatility in the movement of RER is also assessed in any further study apart from RER misalignment, as such movements have impacted more on the growth rather than RER misalignment in some empirical analysis done elsewhere. 


\section{References}

Aguirre, A and C. Calderon, "Real exchange rate misalignments and economic performance", Working Paper No. 315, Central Bank of Chile, 2005

Aizenman, J, and J. Lee, "International Reserves: Precautionary Versus Mercantilist Views, Theory and Evidence." Open Economies Review, 18(2): 191-214, 2007

Athukorala, P., "Post-crisis Export Performance in Thailand", ASEAN Economic Bulletin, 211:19-36, 2004

Athukorala, P. and J. Menon, "Global Production Sharing, Trade Patterns, and Determinants of Trade Flows in East Asia", Working Papers on Regional Economic Integration, No. 41, Asian Development Bank, 2010

Athukorala, P., "Manufacturing Exports from Sri Lanka: Opportunities, achievements and policy Options", Working Papers in Trade Development, Australian National University, 2017

Bouoiyour J., "Exchange Rate Regime, Real Exchange Rate, Trade Flows and Foreign Direct Investments: The Case of Morocco", African Development Review, 17: 2, 2005

Central Bank of Sri Lanka, Annual Report 2003, Central Bank of Sri Lanka, Colombo, 2003

Cheung, Y. et al., " The overvaluation of Renminbi undervaluation", Journal of International Money and Finance, No. 26, 2007

Cottani, J. A. et al., "Real exchange rate behavior and economic performance in LDCs". Economic Development and Cultural Change, 39, pp. 61-76, 1990

Davidson, R. and J. G. MacKinnon, Estimation and Inference in Econometrics. New York: Oxford University Press, 1993

Doroodian K. , "Estimating the Equilibrium Real Exchange Rate: The Case of Turkey", Journal of Applied Economics, 34:14. 2002

Edwards S., Real exchange rates, Devaluation, and Adjustment. The MIT Press, 1989

Ekanayake. N, "Determinants of External Demand for Textiles and Garments of Sri Lanka", Staff Studies, Vol 43, Central Bank of Sri Lanka. 19, 2013

Ghura D and T. J. Grennes, "The real exchange rate and macroeconomic performance in Sub-Saharan Africa", Journal of Development Economics, Vol. 42. 1993

Haddad, M and C. Pancaro, "Can Real Exchange Rate Undervaluation Boost Exports and Growth in Developing Countries? Yes, But Not for Long", Economic Premise, No.20, The World Bank, 2010

Hausmann, R. et al, "Growth Accelerations”, Journal of Economic Growth, 10(4): pp.303-329, 2005

Hendry, D.F., "On the interaction of unit roots and exogeneity", Econometric Reviews, 14(4), pp. 383-419. 1995

Jongwanich, J., "Equilibrium Real Exchange Rate, Misalignment, and Export Performance in Developing Asia", ABD Economic Working Paper Series, No.151, 2009

Kalegama, S., "Impact of Trade Balances: Contemporary Trade Policies and Agreements", Achieving Economic Goals in the midst of Global Challenges, Institute of Policy Studies, 2012

Korinek, A and L. Servén "Undervaluation through Foreign Reserve Accumulation: Static Losses, Dynamic Gains", World Bank Policy Research Working Paper No. 5250, Accessed on 21 March 2017 
Kubota, M., "Real Exchange Rate Misalignment", Department of Economics, University of York, 2009

Pesaran, H., et al., "Bound testing approaches to the analysis of level relationships", Journal of Applied Econometrics, 16(3), 289-326, 2001

Pick D.H and T. L. Vollrath, Real Exchange Rate Misalignment and Agriculture Export Performance in Developing Countries, University of Chicago Press, 42: 3, 1994

Rajan R.S et al., "Misalignment of the Baht and its Trade Balance Consequences for Thailand in the 1980s and 1990s", World Economy, 27: 7, 2004

Razin, O. and S.M. Collins, "Real Exchange Rate Misalignments and Growth", NBER Working Papers 6174, National Bureau of Economic Research, 1997

Rodrik, D., "The Real Exchange Rate and Economic Growth: Theory and Evidence", Brookings Papers on Economic Activity, Fall Conference Draft, 2008

Schröder, M., "Should developing countries undervalue their currencies?", Journal of Development Economics, Elsevier, vol. 105(C), pp. 140-151, 2013

Yajie W, Hui X and S.S. Abdol, "Estimating Renminbi (RMB) Equilibrium Exchange Rate", Journal of Political Model, 29: 3, 2007 


\section{Appendices}

Appendix 1: Trading Partner Countries and Trade Weights used by CBSL in REER $(2010=100)$ compilation

\begin{tabular}{|c|c|}
\hline Country & Weights (per cent) \\
\hline United States & 19.74 \\
\hline India & 15.57 \\
\hline United Kingdom & 9.86 \\
\hline China & 6.41 \\
\hline Germany & 5.88 \\
\hline Japan & 4.99 \\
\hline Itally & 4.83 \\
\hline Belgium & 4.45 \\
\hline Hong Kong & 3.63 \\
\hline France & 2.93 \\
\hline Malaysia & 2.36 \\
\hline Russia & 2.18 \\
\hline Thailand & 2.15 \\
\hline Netherlands & 2.11 \\
\hline Canada & 1.96 \\
\hline Pakistan & 1.8 \\
\hline Singapore & 1.79 \\
\hline Indnesia & 1.73 \\
\hline Turkey & 1.52 \\
\hline Taiwan & 1.51 \\
\hline Korea & 1.17 \\
\hline Australia & 0.97 \\
\hline Bangladesh & 0.36 \\
\hline Kenya & 0.1 \\
\hline
\end{tabular}




\section{Appendix 2: Descriptive Statistics}

\begin{tabular}{|c|c|c|c|c|c|c|c|}
\hline & $\begin{array}{l}\text { REER } \\
24 \\
(\text { level) }\end{array}$ & $\begin{array}{l}\text { Productivity } \\
\text { Differential }\end{array}$ & $\begin{array}{c}\text { Net } \\
\text { Foreign } \\
\text { Assets }\end{array}$ & $\begin{array}{c}\text { Interest } \\
\text { rate } \\
\text { Differential }\end{array}$ & $\begin{array}{l}\text { Government } \\
\text { Consumption } \\
\text { to GDP }\end{array}$ & $\begin{array}{l}\text { Terms } \\
\text { of Trade }\end{array}$ & $\begin{array}{c}\text { Trade } \\
\text { as a } \\
\text { percent } \\
\text { of } \\
\text { GDP }\end{array}$ \\
\hline Mean & 88.7 & 1.5 & 118.9 & 9.0 & 21.8 & 112.6 & 51.9 \\
\hline Median & 95.1 & 1.4 & 153.8 & 9.0 & 22.7 & 108.5 & 50.6 \\
\hline Maximum & 107.2 & 2.8 & 235.4 & 12.1 & 26.1 & 134.0 & 73.3 \\
\hline Minimum & 66.6 & 0.6 & -206.2 & 6.3 & 18.1 & 94.1 & 34.7 \\
\hline Std. Dev. & 13.8 & 0.7 & 116.6 & 1.4 & 2.6 & 15.6 & 12.1 \\
\hline Skewness & -0.2 & 0.3 & -1.2 & 0.0 & -0.2 & 0.2 & 0.2 \\
\hline Kurtosis & 1.3 & 1.6 & 3.6 & 2.1 & 1.6 & 1.3 & 1.6 \\
\hline Jarque-Bera & 7.8 & 5.8 & 15.7 & 2.1 & 5.6 & 7.8 & 5.4 \\
\hline Probability & 0.0 & 0.1 & 0.0 & 0.3 & 0.1 & 0.0 & 0.1 \\
\hline Observations & 63 & 60 & 60 & 61 & 62 & 62 & 62 \\
\hline
\end{tabular}


Appendix 3: Long-run relationship between REER and its Fundamentals

\begin{tabular}{|c|c|c|c|}
\hline & \multicolumn{3}{|c|}{ Dep. Var.: REER 24} \\
\hline & Scenario 1 & Scenario 2 & Scenario 3 \\
\hline \multirow[t]{2}{*}{ Productivity Improvement } & $29.95^{* * *}$ & $27.18^{* * *}$ & $36.86^{* * *}$ \\
\hline & {$[-6.98]$} & {$[-7.37]$} & {$[-8.19]$} \\
\hline \multirow[t]{2}{*}{ Net Foreign Assets } & $0.03^{* *}$ & $0.03^{* * *}$ & $0.03^{* * *}$ \\
\hline & {$[5.07]$} & {$[-5.22]$} & {$[-4.61]$} \\
\hline \multirow[t]{2}{*}{ Terms of Trade } & $0.24^{* * *}$ & $0.19^{* *}$ & $0.28^{* * *}$ \\
\hline & {$[3.31]$} & {$[-2.98]$} & {$[-3.39]$} \\
\hline \multirow[t]{2}{*}{ Trade as a per cent of GDP } & $-0.39 * * *$ & $-0.41^{* * *}$ & -0.20 \\
\hline & {$[3.50]$} & {$[4.07]$} & {$[1.60]$} \\
\hline \multirow[t]{2}{*}{ Government Consumption to GDP } & $1.72 * *$ & $1.55^{* * *}$ & $1.62^{* * *}$ \\
\hline & {$[-3.83]$} & {$[-3.86]$} & {$[-3.16]$} \\
\hline \multirow[t]{2}{*}{ Interest rate differential } & $1.08^{* * *}$ & $1.12^{* * *}$ & $1.17 * * *$ \\
\hline & {$[-4.15]$} & {$[-5.09]$} & {$[-4.26]$} \\
\hline \multirow[t]{2}{*}{ Constant } & -14.41 & $-2.44 * * *$ & $-3.34 * * *$ \\
\hline & {$[0.27]$} & {$[-3.29]$} & {$[-4.22]$} \\
\hline \multirow[t]{2}{*}{ Dummy variable for civil war } & $3.57 * *$ & $3.45^{* * *}$ & $4.76^{* * *}$ \\
\hline & {$[3.39]$} & {$[3.78]$} & {$[4.61]$} \\
\hline \multirow[t]{2}{*}{ Net forex sales } & 0.0003 & 0.0004 & \\
\hline & {$[0.31]$} & {$[0.48]$} & \\
\hline \multirow[t]{2}{*}{ Dummy Variable for Tsunami } & -0.18 & & \\
\hline & {$[-0.17]$} & & \\
\hline \multirow[t]{2}{*}{ Error Correction Term } & $-0.34 * * *$ & $-0.37 * * *$ & $-0.31 * * *$ \\
\hline & {$[-3.98]$} & {$[-4.33]$} & {$[-4.87]$} \\
\hline Number of observations & 58 & 58 & 58 \\
\hline
\end{tabular}


Appendix 4: Descriptive Statistics: Estimation of Export Demand Functions

\begin{tabular}{lcccccc}
\hline & $\begin{array}{c}\text { Total } \\
\text { Export } \\
\text { Volume } \\
\text { Index (log) }\end{array}$ & $\begin{array}{c}\text { Industrial } \\
\text { export } \\
\text { Volume } \\
\text { Index (log) }\end{array}$ & $\begin{array}{c}\text { Agriculture } \\
\text { Export } \\
\text { Volume } \\
\text { Index (log) }\end{array}$ & $\begin{array}{c}\text { log REER } \\
24\end{array}$ & $\begin{array}{c}\text { log Real } \\
\text { GDP }\end{array}$ & $\begin{array}{c}\text { Trading } \\
\text { partner's real } \\
\text { GDP (log) }\end{array}$ \\
\hline Mean & 4.5 & 4.7 & 4.6 & 4.5 & 14.2 & 4.6 \\
Median & 4.5 & 4.8 & 4.6 & 4.5 & 14.1 & 4.6 \\
Maximum & 4.9 & 5.0 & 4.7 & 4.7 & 14.6 & 4.8 \\
Minimum & 4.1 & 4.4 & 4.5 & 4.2 & 13.7 & 4.4 \\
Std. Dev. & 0.2 & 0.2 & 0.0 & 0.2 & 0.3 & 0.1 \\
Skewness & -0.1 & 0.0 & 0.4 & -0.3 & 0.0 & -0.1 \\
Kurtosis & 1.8 & 1.6 & 2.3 & 1.4 & 1.6 & 2.0 \\
Jarque-Bera & 3.6 & 3.5 & 2.4 & 7.7 & 4.8 & 2.7 \\
$\quad$ Probability & 0.2 & 0.2 & 0.3 & 0.0 & 0.1 & 0.3 \\
Observations & 63 & 43 & 43 & 63 & 62 & 61 \\
\hline
\end{tabular}




\section{Appendix 5: Stability Tests}

\section{Total Export function}

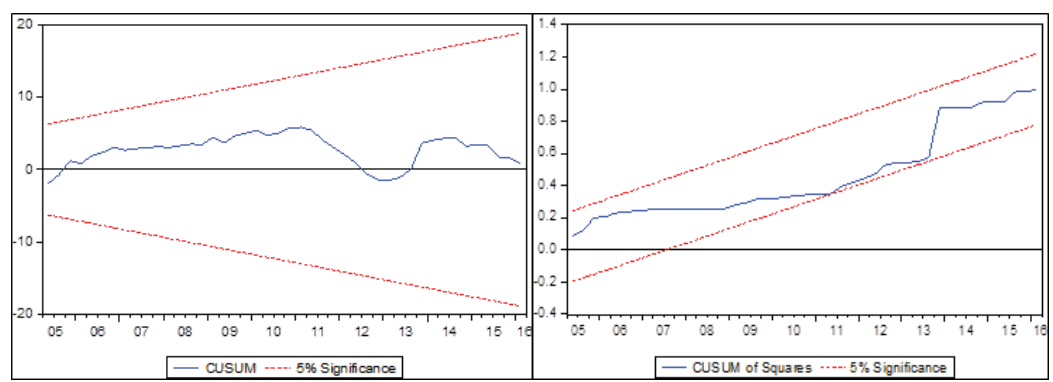

\section{Total Industrial Export function}

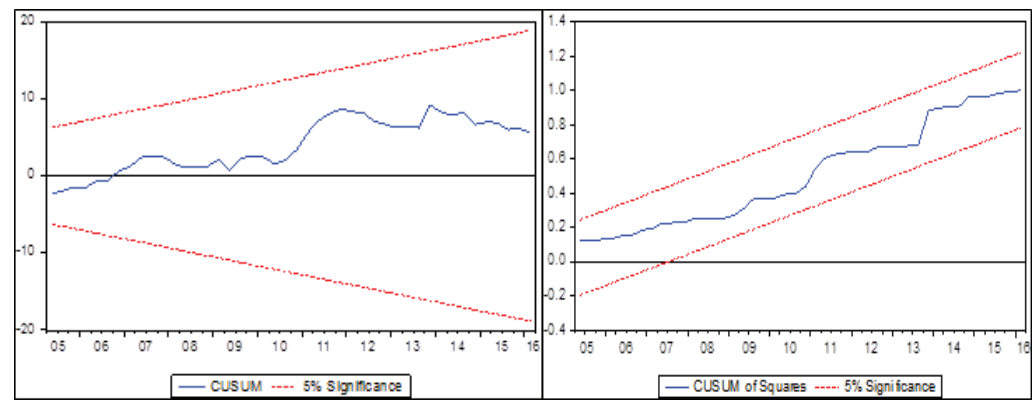

\section{Textile and Garments Exports function}

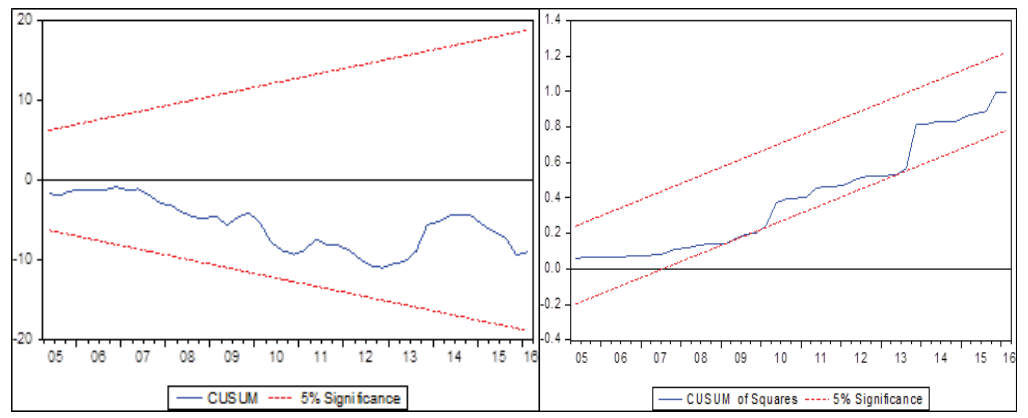

